\title{
Safety of immediate reversal of anticoagulation by protamine to reduce bleeding complications after infarct artery stenting for acute myocardial infarction and adjunctive abciximab therapy
}

\author{
Guido Parodi - Giuseppe De Luca • Guia Moschi • \\ Benedetta Bellandi · Renato Valenti • Angela Migliorini • \\ Nazario Carrabba $\cdot$ David Antoniucci
}

Published online: 23 June 2010

(C) The Author(s) 2010. This article is published with open access at Springerlink.com

\begin{abstract}
Infarct artery stenting with adjunctive abciximab therapy is widely used treatment for patients with acute myocardial infarction (AMI). However, bleeding complications have been associated with a worse clinical outcome. Randomized trials in elective patients have shown that postprocedural protamine administration is safe and associated with a significant reduction in bleeding complications. The aim of the current study was to evaluate in STEMI patients undergoing primary percutaneous coronary intervention (PCI) with abciximab and stenting whether immediate reversal of anticoagulation by protamine is safe and associated with a reduction in the occurrence of bleeding complications. From January 2004 to June 2005, 254 patients with STEMI had immediate reversal of anticoagulation by protamine administration after infarct artery stenting and received abciximab therapy without heparin infusion (Group 1). These patients were compared with a control group of 265 patients (June 2002-December 2003) treated with the standard heparin therapy: bolus in order to achieve an activated coagulation time of 250-300 s during PCI plus 12-h infusion (7 UI/kg/h; Group 2). We excluded patients undergoing IABP implantation. The two groups were similar in all baseline characteristics. There were no differences in in-hospital mortality, reinfarction, urgent target vessel revascularization, stroke or acute or subacute stent thrombosis, while Group 1 patients showed a lower
\end{abstract}

G. Parodi - G. De Luca - G. Moschi - B. Bellandi - R. Valenti ·

A. Migliorini · N. Carrabba · D. Antoniucci

Division of Cardiology, Careggi Hospital, Florence, Italy

G. De Luca $(\square)$

Division of Cardiology, "Maggiore della Carità" Hospital,

Eastern Piedmont University “A. Avogadro”, Novara, Italy

e-mail: giuseppe.deluca@maggioreosp.novara.it;

p.de_luca@libero.it incidence of major bleeding complications (ACUITY scale: 1.1 vs. $4.0 \%, P=0.035)$ and a shorter length of hospital stay $(3.5 \pm 1.7$ vs. $4.0 \pm 1.6$ days, $P=0.002)$ as compared with heparin treated patients. Among patients undergoing primary stenting with abciximab administration, immediate post-PCI reversal anticoagulation by protamine without associated heparin infusion is safe and associated with a significant reduction in major bleeding complications.

Keywords Acute myocardial infarction - Stent .

Abciximab · Platelets · Anticoagulation

\section{Introduction}

Routine infarct artery stenting and abciximab as adjunctive therapy is currently considered the preferred treatment for patients with ST-segment elevation myocardial infarction (STEMI) [1], notwithstanding the increased risk of bleeding complications due to the associated anticoagulation state produced by heparin. Post-procedure heparin infusion was used in all the five concluded randomized trials [2-6] of primary percutaneous coronary intervention (PCI) comparing abciximab with placebo, and after the EPIC trial [7] that showed an excess in bleeding in patients receiving abciximab and heparin, in the other trials the dosage of heparin infusion was lowered with subsequent bleeding rate similar to the one of patients receiving heparin alone without any decreased benefit in terms of ischemic complications. We hypothesized that the maintenance of an anticoagulation state by heparin after PCI is a major determinant of bleeding complications while has only limited impact on the prevention of post-PCI ischemic complications. Thus, we assessed the safety and efficacy of 
immediate reversal of anticoagulation by protamine after PCI followed by abciximab 12-h infusion without associated heparin infusion.

\section{Methods}

\section{Study population}

From January 2004 to June 2005 a strategy of routine reversal of anticoagulation state by protamine at the end of primary PCI followed by 12-h abciximab infusion without adjunctive heparin infusion was adopted. During this period a total of 310 patients underwent primary stenting with abciximab administration. The clinical outcome of these patients was compared with the one of a control group of 305 patients treated in the previous 18 months with standard heparin anticoagulation (bolus during PCI in order to achieve an activated coagulation time of $250-300 \mathrm{~s}$ followed by $12 \mathrm{~h}$ infusion during abciximab infusion (Group 2). Ninety-six patients (56 in the Group 1 and 40 in the Group 2) who required intra-aortic pump implantation during or after PCI or with suboptimal procedural success (TIMI $<3$ or residual stenosis $>50 \%$ ) were excluded from the analysis because of established need of heparin infusion. Thus our final population is represented by 254 patients in Group 1 and 265 patients in Group 2.

Criteria for primary PCI and infarct artery stenting with adjunctive abciximab therapy were: (1) chest pain persisting more than $30 \mathrm{~min}$ associated with ST-segment elevation of at least $0.1 \mathrm{mV}$ in 2 or more contiguous electrocardiographic leads, (2) admission within $12 \mathrm{~h}$ of symptom, and (3) reference infarct artery diameter $\geq 2.5 \mathrm{~mm}$ on visual assessment or smaller vessels with nonoptimal result after balloon angioplasty. Contraindications for abciximab therapy were: previous fibrinolytic therapy, history of bleeding diathesis or allergy to the study drugs, major surgery within 15 days, active bleeding.

\section{Treatments}

Before catheterization patients received $325 \mathrm{mg}$ of aspirin orally, or $250 \mathrm{mg}$ intravenously. Abciximab (ReoPro, Centocor, Malvern, PA) was administered immediately before the procedure as a bolus of $0.25 \mathrm{mg} / \mathrm{kg}$ of body weight followed by a 12-h infusion at a rate of $0.125 \mu \mathrm{g} /$ $\mathrm{kg} / \mathrm{min}$. Heparin was given as an initial bolus of $70 \mathrm{UI} / \mathrm{kg}$, and additional boluses were administered during the procedure to achieve an activated clotting time of 250-300 s. Group 1 patients had reversal anticoagulation state (defined as activated clotting time $<150 \mathrm{~s}$ ) by the administration of $25-50 \mathrm{mg}$ of protamine at the end of the procedure, while
Group 2 patients continued low dose heparin infusion ( $7 \mathrm{UI} / \mathrm{kg} / \mathrm{h}$ ) for $12 \mathrm{~h}$. Both groups had sheath removal (femoral approach) at the end of the procedure, and hemostasis was achieved by the use of closure devices or manual compression after failure of closer device attempt. Clopidogrel (300 or $600 \mathrm{mg}$ ) or ticlopidine $(500 \mathrm{mg}$ ) was administered after the procedure in all patients. Patients were thereafter treated with aspirin $(100 \mathrm{mg} /$ day indefinitely), and clopidogrel $(75 \mathrm{mg} /$ day $)$ or ticlopidine (500 $\mathrm{mg} /$ day) for at least 3 months.

\section{End-points and outcome measures}

The primary safety end-point was the incidence of in-hospital major adverse cardiac events (death from any cause, nonfatal reinfarction, target vessel revascularization and stroke), while the primary efficacy end-point was the incidence of major bleeding complications according to the Acute Catheterization and Urgent Intervention Triage strategY (ACUITY) scale [8]. Major bleedings were evaluated also according to the Thrombolysis In Myocardial Infarction (TIMI) criteria [9]. Reinfarction was defined as recurrent chest pain with ST-segment or T-wave changes and recurrent elevation of cardiac enzymes. Stent thrombosis was defined as angiographic documentation of target vessel occlusion or any death or reinfarction that is not clearly related to causes other than stent occlusion. Target vessel revascularization was defined as coronary angioplasty or coronary surgery performed due to restenosis or reocclusion of the infarct artery.

\section{Statistical analysis}

Discrete data are summarized as frequencies, while continuous as mean $\pm \mathrm{SD}$. Chi-square test analysis was used for comparison of categorical variables. Student $t$ test was used to test differences among continuous variables. All analyses were conducted according to the intention-to-treat principle. A $P$ value $<0.05$ was considered significant. Analyses were performed with SPSS for Windows, version 11.5 (SPSS Inc., Chicago, Illinois).

\section{Results}

The two groups were similar in all baseline clinical and procedural characteristics (Table 1). Femoral access was used in nearly all patients of both groups. Maintenance of anticoagulation after PCI by heparin for at least $12 \mathrm{~h}$ in Group 1 occurred in 15 patients $(6 \%)$ based on operator's decision, while early discontinuation of heparin infusion was observed in 11 patients (4\%) of Group 2. 
Table 1 Baseline clinical and procedural characteristics
TIMI Thrombolysis In Myocardial Infarction

\section{Clinical outcome}

There were no differences in the incidence of death, myocardial infarction, target vessel revascularization and stroke between groups during hospitalization (Table 2) and at 6 months (Fig. 1). The cause of in-hospital death was refractory heart failure in most cases of both groups while one death occurred as a consequence of fatal reinfarction in Group 2. In the analysis restricted to high-risk patients, such as those ones with multivessel disease $(n=240)$, no difference in in-hospital death (4.1 vs. $3.4 \%, P=0.95)$ and in acute or subacute stent thrombosis ( 0.8 vs. $0.8 \%$, $P=0.9)$ was observed between the two groups.

The incidence of in-hospital major bleeding was more than threefold lower in Group 1 as compared to Group 2 (Table 3). Most of the major bleeding complications occurred at the artery entry site, while fatal bleeding occurred in one patient of Group 2. A trend towards a decreased major bleeding rate was revealed using the more stringent TIMI criteria ( 0.4 vs. $2.2 \%, P=0.062)$. The length of hospital stay was lower in Group 1 as compared to Group 2 ( $3.5 \pm 1.7$ vs. $4.0 \pm 1.6$ days, $P=0.002)$.

\section{Discussion}

The EPIC study results [7] raised the important question regarding the balance between hemorrhagic risk and clinical benefit with abciximab therapy and standard-dose heparin during PCI. In the EPILOG Trial [10], abciximab with a reduced-dose heparin treatment showed a lower incidence of major bleeding complications as compared to abciximab with a standard-dose heparin, without affecting the effectiveness of the prevention of PCI ischemic complications. However, bleeding complication after PCI and adjunctive glycoprotein IIb/IIIa inhibition with anticoagulant treatment remains a major issue with significant impact on short and long-term clinical outcomes [11]. Heparin has
Table 2 Safety end-points

$C K$ creatine kinase

a MACE major adverse cardiac events (death or reinfarction or target vessel revascularization)

\begin{tabular}{llll}
\hline & $\begin{array}{l}\text { Abciximab alone } \\
(\mathrm{n}=254)\end{array}$ & $\begin{array}{l}\text { Abciximab plus heparin } \\
(\mathrm{n}=265)\end{array}$ & $P$ value \\
\hline In-hospital outcomes & & & \\
Death & $4(1.6 \%)$ & $4(1.5 \%)$ & 0.961 \\
Reinfarction & $2(0.8 \%)$ & $1(0.4 \%)$ & 0.538 \\
Target vessel revascularization & $1(0.4 \%)$ & $2(0.8 \%)$ & 0.264 \\
Overall MACE & $6(2.4 \%)$ & $7(2.6 \%)$ & 0.839 \\
Stroke & $2(0.8 \%)$ & $1(0.4 \%)$ & 0.538 \\
Acute or subacute stent thrombosis & $2(0.8 \%)$ & $1(0.4 \%)$ & 0.538 \\
Peak CK value (U/L) & $2466 \pm 2331$ & $2231 \pm 2134$ & 0.232 \\
Time-to-peak CK (h) & $7.2 \pm 6.5$ & $6.5 \pm 3.6$ & 0.465 \\
Thrombocytopenia (<100 $\left.\times 10^{9} / \mathrm{l}\right)$ & $0(0 \%)$ & $3(1 \%)$ & 0.089 \\
Congestive heart failure & $5(2.0 \%)$ & $11(4.1 \%)$ & 0.151 \\
Hospitalization length (days) & $3.4 \pm 1.4$ & $3.9 \pm 1.6$ & 0.0001 \\
\hline
\end{tabular}




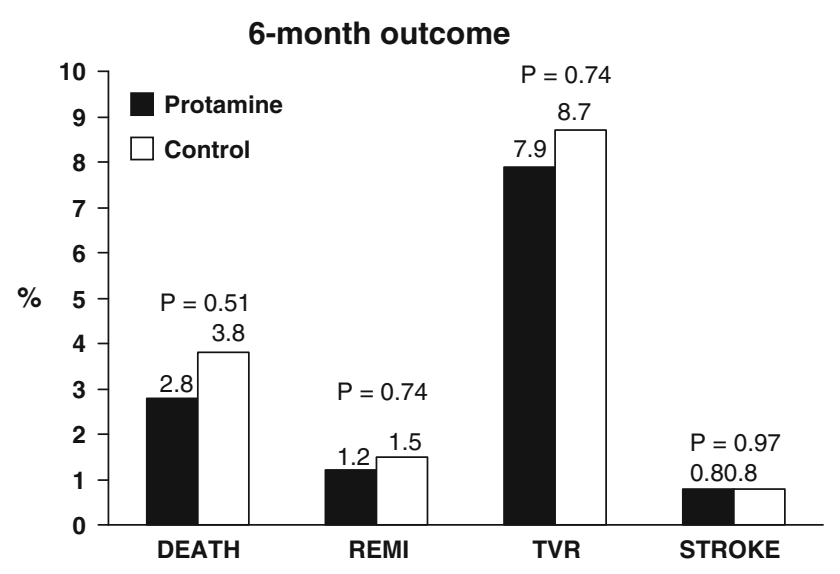

Fig. 1 Six-month clinical outcome of patients receiving postprocedural protamine (Group 1, black bars) or 12-h heparin infusion (Group 2, white bars)

shortcomings such as indirect inhibition of antithrombin III, which levels may be quite variable, and it bounds to nonspecific circulating proteins. As a consequence the response to the drug is unpredictable. Recent concluded randomized Trials assessed different antithrombotic strategies in order to reduce the incidence of bleeding without increase in ischemic complications [12-14].

Since the first documentation by Jaques [15], protamine has been used clinically to promptly reverse the anticoagulant effect of heparin. It must be recognized that protamine is currently largely and safely used after heart surgery, including patients receiving mechanical prosthesis. However, reversal of heparin effect with the administration of protamine may potentially induce hypotension, platelet aggregation, and thrombus formation [16-18]. These fears have refrained from a larger application to promote early sheath removal after PCI.

Several reports have investigated so far the safety of routine application of protamine and early sheath removal after coronary stenting. Pan et al. [19] randomized 228 patients after successful stent implantation to protamine and in-laboratory sheath removal versus no protamine and delayed sheath removal. No death and in-stent thrombosis were observed in both groups, with shorter hospital stay in patients receiving protamine. In a series of 429 consecutive patients undergoing successful PCI (85\% stenting), Ducas et al. [20] showed that postprocedural protamine administration and early sheath removal was safe with no case of in-laboratory complications and no death at 30-day followup, with very low rate of bleeding complications. The safety of protamine administration has been shown by Briguori et al. in 90 patients undergoing coronary stenting [21].

Thuesen et al. [22] analyzed the safety and benefits from protamine administration and early sheath removal in a very large cohort of patients undergoing elective PCI between January 1999 and December 2002. There were 1.129 patients (Group 1) admitted between January 1999 to December 1999, with sheath removal $4 \mathrm{~h}$ after the PCI procedure, whereas 4.193 patients (Group 2), admitted between January 2000 to December 2002, underwent protamine sulphate administration and early sheath removal. The rates of stent thrombosis, non-fatal myocardial infarction and in-hospital mortality were similar in the two groups. The rate of puncture site complications were significantly lower with protamine and early sheath removal ( 2.6 vs. $4.7 \%, P<0.001)$. Finally, the safety of heparin reversal by protamine, as compared to the short half-life anticoagulant bivalirudin, has recently been shown in our randomized trial including 850 patients undergoing elective PCI [23].

Despite the safety of protamine administration largely shown in elective successful stenting, no data have been so far reported in patients with STEMI, where the risk of thrombotic complications may be potentially higher than in elective patients after rapid reversal of heparin.

However, it must be recognized that the HORIZONS trial [14] has recently demonstrated that anticoagulation therapy after successful primary PCI is no longer needed. In this study more than 3000 STEMI patients undergoing primary angioplasty were randomized to bivalirudin or
Table 3 Major bleeding complications

\begin{tabular}{llll}
\hline & $\begin{array}{l}\text { Abciximab alone } \\
(\mathrm{n}=254)\end{array}$ & $\begin{array}{l}\text { Abciximab plus heparin } \\
(\mathrm{n}=265)\end{array}$ & $P$ value \\
\hline Major bleedings (ACUITY scale) & $3(1.1 \%)$ & $11(4.0 \%)$ & 0.035 \\
Intracranial bleeding & 0 & 1 & \\
Access site hemorrage requiring intervention & 0 & 3 \\
$\geq 5 \mathrm{~cm}$ diameter hematoma & 0 & 2 \\
$\begin{array}{l}\text { Reduction in hemoglobin concentration } \\
\text { of } \geq 4 \text { g/dl without an overt source of bleeding }\end{array}$ & 1 & 1 \\
$\begin{array}{l}\text { Reduction in hemoglobin concentration } \\
\text { of } \geq 3 \text { g/dl with an overt source of bleeding }\end{array}$ & 0 & 3 \\
\begin{tabular}{l} 
Use of any blood product transfusion \\
\hline
\end{tabular} & 2 & 3
\end{tabular}


heparin and glycoprotein IIb-IIIa inhibitors. Since bivalirudin has a 25-min half-life, the risk of thrombotic complications with bivalirudin would have expected to be higher as compared to heparin plus glycoprotein IIb/IIIa inhibitors. However, the slightly higher risk of early $(\leq 24 \mathrm{~h})$ stent thrombosis is explained by the suboptimal inhibition of platelet aggregation as compared to adjunctive administration of glycoprotein IIb-IIIa inhibitors. Remarkably, bivalirudin was associated with a significant reduction in bleeding complications and a lower mortality as compared to heparin plus glycoprotein IIb/IIIa inhibitors.

To the best of our knowledge, this is the first study investigating the potential safety and benefits of protamine administration in patients undergoing primary angioplasty. The results of this study show that post-PCI anticoagulation reversal by protamine and routine abciximab therapy in patients receiving primary infarct artery stenting is not associated with an increase in ischemic complications while the incidence of major bleeding is strongly reduced and the length of in hospital stay significantly shortened. Notably, the incidence of acute and subacute stent thrombosis and of reinfarction was very low in both groups, regardless of protamine administration. The results were confirmed in high-risk patients, such as those with multivessel disease.

Thus, the results of our study are consistent with those in elective patients and exclude the hypothesis of a rebound pro-thrombotic state after immediate heparin neutralization due to heparin activated platelets or a heparin rebound with reappearance of anticoagulant activity after protamine administration.

Future randomized trials are certainly needed to investigate whether bivalirudin is still superior in terms of mortality as compared to a strategy of heparin, abciximab and early postprocedural sheath removal pending protamine administration, in patients undergoing primary PCI for STEMI in the era of new generation antiplatelets agents [24-25].

\section{Study limitations}

Our results must be evaluated in the light of some study limitations. This was a nonrandomized study. However, only unselected and consecutive patients were enrolled, and the two study groups were similar in baseline characteristics. The shorter length of hospital stay of the more recent group might be, at least in part, due to the fact that the length of hospital stay for STEMI has decreased worldwide in recent years. However, we adopted an early discharge strategy before the beginning of study enrolment and post-procedure heparin infusion was related to the hospital stay length. The relatively small size may have affected the results and made the study underpowered to evaluate a strong endpoint, such as mortality. Postprocedural Heparin infusion is not recommended anymore, and it might have favoured the benefits observed in our study in terms of bleeding complications with protamine administration. A propensity score analysis was not performed, being the groups homogeneous with no difference in baseline characteristics, except than of Heparin infusion (as per protocol).

\section{Conclusions}

The strategy of routine immediate reversal of anticoagulation state after primary infarct artery stenting for STEMI with routine abciximab as adjunctive therapy seems safe and associated with a strong reduction in major bleeding complications and with a shorter hospital stay. Thus, our study, confirming recent findings of the HORIZONS trial, suggest that prolonged blood anticoagulation is not longer needed after primary PCI, especially with adjunctive use of glycoprotein IIb-IIIa inhibitors. However, future randomized trials are certainly needed to confirm our findings and to compare this strategy to the use of bivalirudin in the era of new antiplatelet compounds.

Open Access This article is distributed under the terms of the Creative Commons Attribution Noncommercial License which permits any noncommercial use, distribution, and reproduction in any medium, provided the original author(s) and source are credited.

\section{References}

1. Topol EJ, Neumann F-J, Montalescot G (2003) A preferred reperfusion strategy for acute myocardial infarction. J Am Coll Cardiol 42:1886-1889

2. Brener SJ, Barr LA, Burchenal JE, Katz S, George BS, Jones AA, Cohen ED, Gainey PC, White HJ, Cheek HB, Moses JW, Moliterno DJ, Effron MB, Topol EJ (1998) Randomized, placebocontrolled trial of platelet glycoprotein IIb/IIIa blockade with primary angioplasty for acute myocardial infarction; Reopro and Primary PTCA Organization and Randomized trial (RAPPORT) Investigators. Circulation 98:734-741

3. Neumann F-J, Kastrati A, Schmitt C, Blasini R, Hadamitzky M, Mehilli J, Gawaz M, Schleef M, Seyfarth M, Dirschinger J, Schomig A (2000) Effect of glycoprotein IIb/IIIa receptor blockade with abciximab on clinical and angiographic restenosis rate after the placement of coronary stents following acute myocardial infarction. J Am Coll Cardiol 35:915-921

4. Montalescot G, Barragan P, Wittenberg O, Ecollan P, Elhadad S, Villain P, Boulenc JM, Morice MC, Maillard L, Pansieri M, Choussat R, Pinton p (2001) Abciximab before direct angioplasty and stenting in myocardial infarction regarding acute and longterm follow-up. Platelet glycoprotein IIb/IIIa inhibition with coronary stenting for acute myocardial infarction. N Engl J Med 344:1895-1903 
5. Stone GW, Grines CL, Cox DA, Garcia E, Tcheng JE, Griffin JJ, Guagliumi G, Stuckey T, Turco M, Carroll JD, Rutherford BD, Lansky AJ (2002) Controlled Abciximab and Device Investigation to Lower Late Angioplasty Complications (CADILLAC) Investigator. Comparison of angioplasty with stenting, with or without abciximab, in acute myocardial infarctions. $\mathrm{N}$ Engl $\mathrm{J}$ Med 346:957-966

6. Antoniucci D, Rodriguez A, Hempel A, Valenti R, Migliorini A, Vigo F, Parodi G, Fernandez-Pereira C, Moschi G, Bartorelli A, Santoro GM, Bolognese L, Colombo A (2003) A randomized trial comparing primary infarct artery stenting with or without abciximab in acute myocardial infarction. J Am Coll Cardiol 42:1879-1885

7. EPIC investigators (1994) Use of the monoclonal antibody directed against the platelet glycoprotein IIb/IIIa receptor in high risk coronary angioplasty. N Engl J Med 330:956-961

8. Stone GW, Bertrand M, Colombo A, Dangas G, Farkouh ME, Feit F, Lansky AJ, Lincoff AM, Mehran R, Moses JW, Ohman M, White HD (2004) Acute Catheterization and Urgent Intervention Triage strategY (ACUITY) trial: study design and rationale. Am Heart J 148:764-775

9. Chesebro JH, Knatterud G, Roberts R, Borer J, Cohen LS, Dalen J, Dodge HT, Francis CK, Hillis D, Ludbrook P (1987) The thrombolysis in myocardial infarction (TIMI) trial, Phase I: a comparison between intravenous tissue plasminogen activator and intravenous streptokinase. Circulation 76:142-154

10. EPILOG investigators (1997) Platelet glycoprotein IIb/IIIa receptor blockade and low-dose heparin during percutaneous coronary revascularization. N Engl J Med 336:1689-1696

11. Rao SV, O'Grady K, Pieper KS, Granger CB, Newby LK, Mahaffey KW, Moliterno DJ, Lincoff AM, Armstrong PW, Van de Werf F, Califf RM, Harrington RA (2006) A comparison of the clinical impact of bleeding measured by two different classifications among patients with acute coronary syndromes. J Am Coll Cardiol 47:809-816

12. Lincoff AM, Bittl JA, Harrington RA, Feit F, Kleiman NS, Jackman JD, Sarembock IJ, Cohen DJ, Spriggs D, Ebrahimi R, Keren G, Carr J, Cohen EA, Betriu A, Desmet W, Kereiakes DJ, Rutsch W, Wilcox RG, de Feyter PJ, Vahanian A, Topol EJ, REPLACE-2 Investigators (2003) Bivalirudin and provisional glycoprotein IIb/IIIa blockade compared with heparin and planned glycoprotein IIb/IIIa blockade during percutaneous coronary intervention: REPLACE-2 randomized trial. JAMA 289:853-863

13. Stone GW, McLaurin BT, Cox DA, Bertrand ME, Lincoff AM, Moses JW, White HD, Pocock SJ, Ware JH, Feit F, Colombo A, Aylward PE, Cequier AR, Darius H, Desmet W, Ebrahimi R, Hamon M, Rasmussen LH, Rupprecht HJ, Hoekstra J, Mehran R, Ohman EM, ACUITY Investigators (2006) Bivalirudin for patients with acute coronary syndromes. N Engl J Med 355:22032216

14. Mehran R, Lansky AJ, Witzenbichler B, Guagliumi G, Peruga JZ, Brodie BR, Dudek D, Kornowski R, Hartmann F, Gersh BJ, Pocock SJ, Wong SC, Nikolsky E, Gambone L, Vandertie L,
Parise H, Dangas GD, Stone GW (2009) HORIZONS-AMI Trial Investigators. Bivalirudin in patients undergoing primary angioplasty for acute myocardial infarction (HORIZONS-AMI): 1-year results of a randomised controlled trial. Lancet 374:1149-1159

15. Jaques LB (1973) Protamine antagonist to heparin. J Can Med Assoc 108:1291-1297

16. Horrow JC (1985) Protamine: a review of its toxicity. Anesth Analg 64:348-361

17. Click RL, Hamburger HA, Bove AA (1989) Complement activation from protamine sulfate after coronary angiography. Cathet Cardiovasc Diagn 16:221-225

18. Evora PRB, Pearson PJ, Schaff HV (1995) Protamine indices endotheliumdependent vasodilatation of the pulmonary artery. Ann Thorac Surg 60:405-410

19. Pan M, Suarez de Lezo J, Medina A, Romero M, Hernandez E, Segura J, Melian F, Wanguemert F, Landin M, Benitez F, Amat M, Velasco F, Torres A (1997) In-laboratory removal of femoral sheath following protamine administration in patients having intra-coronary stent implantation. Am J Cardiol 80:1336-1338

20. Ducas J, Chan MC, Miller A, Kashour T (2002) Immediate protamine administration and sheath removal following percutaneous coronary intervention: a prospective study of 429 patients. Catheter Cardiovasc Interv 56:196-199

21. Briguori C, Di Mario C, De Gregorio J, Sheiban I, Vaghetti M, Colombo A (1999) Administration of protamine after coronary stent deployment. Am Heart J 138:64-68

22. Thuesen L, Andersen HR, Bøtker HE, Dalby Kristensen S, Krusell LR, Lassen JF (2005) In-laboratory femoral sheath removal after heparin reversal by protamine after percutaneous coronary intervention. EuroIntervention 1:66-69

23. Parodi G, Migliorini A, Valenti R, Bellandi B, Signorini U, Moschi G, Buonamici P, Cerisano G, Antoniucci D (2010) Comparison of bivalirudin and unfractionated heparin plus protamine in patients with coronary heart disease undergoing percutaneous coronary intervention (from the Antithrombotic Regimens aNd Outcome [ARNO] Trial). Am J Cardiol 105:1053-1059

24. Montalescot G, Wiviott SD, Braunwald E, Murphy SA, Gibson CM, McCabe CH, Antman EM (2009) TRITON-TIMI 38 investigators. Prasugrel compared with clopidogrel in patients undergoing percutaneous coronary intervention for ST-elevation myocardial infarction (TRITON-TIMI 38): double-blind, randomised controlled trial. Lancet 373:723-731

25. Wallentin L, Becker RC, Budaj A, Cannon CP, Emanuelsson H, Held C, Horrow J, Husted S, James S, Katus H, Mahaffey KW, Scirica BM, Skene A, Steg PG, Storey RF, Harrington RA, Freij A, Thorsén M, PLATO Investigators (2009) Ticagrelor versus clopidogrel in patients with acute coronary syndromes. N Engl J Med 361:1045-1057 